\title{
ESCLARECIMENTO (PER) VERSO: Nietzsche à sombra da ilustração
}

\author{
(Per) verse enlightenment: \\ Nietzsche in the shade of illustration
}

\begin{abstract}
Oswaldo Giacoia Junior
Doutorado pela Freie Universität Berlin, F.U.B., Alemanha, Professor do departamento de Filosofia da Unicamp, Campinas, SP - Brasil, e-mail: giacoia@tsp.com.br
\end{abstract}

\begin{abstract}
Resumo
O presente trabalho pretende explorar algumas afinidades, em termos de teoria crítica, entre a Dialética do Esclarecimento e a genealogia da moral de Friedrich Nietzsche. Especial atenção é dedicada à questão da possibilidade de situar a filosofia de Nietzsche no horizonte da Aufklärung e da crítica da modernidade cultural a que também pertencem alguns dos mais importantes trabalhos da Escola de Frankfurt.
\end{abstract}

Palavras-chave: Razão instrumental; Genealogia; Cultura; Esclarecimento; Teoria crítica.

\begin{abstract}
The present study intends to explore some affinities, in terms of critical theory, between the Dialectic of Enlightenment and Friedrich Nietzsche's genealogy of morals. A special attention is given to the question of the possibility of situating Nietzsche's philosophy in the horizon of Enlightenment and of the critic of cultural modernity as well. Indeed, to the latter also belong some of the most important works of the Frankfurt School.
\end{abstract}

Keywords: Instrumental reason; Genealogy; Culture; Enlightenment; Critical theory. 
O principal objetivo do presente trabalho consiste na tentativa de explicitar uma analogia estrutural entre as descrições da lógica e da dinâmica da moderna Aufklãrung, que considero poder detectar no modo como as reconstituem Nietzsche, por um lado, Horkheimer e Adorno, na obra Dialektik der Aufklärung, por outro lado.

A primeira analogia evidente pode ser apreendida já na cesura aberta, nos marcos teóricos do Esclarecimento, entre uma rigorosa e hígida vertente lógicocognitiva, à qual se contrapõe uma vertente ético-moral porosa e vulnerável, gerando uma dialética cujo desenvolvimento acaba por opô-las entre si, levando à crise e à autosupressão da própria Aufklärung. Pode-se descrever em detalhe esse processo, recorrendo a uma interpretação detalhada dos respectivos argumentos.

Tomo como ponto de partida a seguinte consideração de Horkheimer e Adorno:

As doutrinas morais do Esclarecimento testemunham do anseio desesperançado para, em lugar da religião enfraquecida, encontrar um fundamento intelectual para manter-se na sociedade quando o interesse fracassa. Os filósofos compactuam com os poderes que são condenados segundo as doutrinas deles. As teorias são conseqüentes e hígidas, as doutrinas morais propagandísticas e sentimentais, também onde elas soam rigorísticas, ou elas são linhas de violência a partir da consciência da inderivabilidade justamente da moral, como o recurso de Kant às forças éticas como fatos... A raiz do otimismo kantiano, segundo o qual o agir moral seria também razoável onde o agir indigno tivesse boa perspectiva, é o horror perante a recaída na barbárie... Mas as forças éticas não são, todavia, de acordo com Kant, impulsos e modalidades de comportamento menos neutros perante a razão científica do que as não éticas, nas quais aquelas também tão logo se convertem quando, ao invés serem dirigidas para aquela oculta possibilidade [do reino de todos os seres morais, OGJ.], são dirigidas para a conciliação com o poder (HORKHEIMER; ADORNO, 1987, p. 108).

Acredito poder mostrar que a trajetória descrita pela crítica de Nietzsche à moralidade cristã exibe uma espantosa semelhança com o processo acima figurado pelos pensadores de Frankfurt. Para evidenciá-lo, pode-se tomar como fio condutor o destino histórico catastrófico da veracidade (Wahrhaftigkeit), segundo Nietzsche. Essa veracidade, cuja sublimação filosófica o aufklärer Kant já havia consagrado na tríade formada pelas virtudes da Wahrhaftigkeit (veracidade), Redlichkeit (honestidade), Aufrichtigkeit (retidão): 
Oh retidão (Aufrichtigkeit) tu, Astrea, que escapastes da terra para o céu! Como te reconduziremos (o fundamento da consciência moral e, com isso, de toda religião interior) novamente de lá para nós aqui em baixo? Eu posso conceder, conquanto seja muito de se lamentar, que a abertura de coração (que consiste em dizer toda a verdade que se sabe) não se encontra na natureza humana. Porém a sinceridade [que seja dito com veracidade [Wahrhaftigkeit] tudo aquilo que se diz] temos que poder exigir de todo homem, e mesmo se também não existisse em nossa natureza nenhuma disposição para tanto, cuja cultura é apenas negligenciada, a raça humana teria de ser, a seus próprios olhos, um objeto do mais profundo desprezo. (KANT, 1968, p. 190).

Nietzsche compreende a própria obra, bem como o sentido de sua vida, como culminação de um movimento histórico-cultural cujo início se confunde com os primórdios da Aufklärung europeia - em especial sob a forma (pessimista) de seu desdobramento onto-teológico alemão. "Compreende-me? A auto-supressão do moralista em seu contrário - em mim - isso significa em minha boca o nome Zaratustra"(EH 367).

Como se dá esse autoaniquilamento da moral? Por que ele pode ser propriamente denominado de autossupressão? Precisamente porque ele se dá como um paradoxo e como uma catástrofe: trata-se de retirar a confiança na moral, em seus valores supremos, por dever de honestidade intelectual, portanto, a moderna consciência filosófica, cientificamente esclarecida e emancipada, tem o dever moral, de denunciar a moral como um embuste imoral.

O que pretendo enunciar é que tal paradoxo catastrófico só pode ser adequadamente compreendido no horizonte da autocrítica e da autorreflexão da consciência esclarecida: "Transvaloração de todos os valores: esta é minha fórmula para um ato de suprema auto-reflexão da humanidade, que em mim se tornou carne e gênio. Meu destino quer que eu tenha de ser o primeiro homem decente, que eu me saiba em oposição à mendacidade de milênios" (EH 365). Essa exigência se nutre da mesma raiz de que brota o ímpeto libertário do Esclarecimento, ou seja, a ideia essencialmente emancipatória de retirar o homem dos grilhões da superstição e da ignorância, sobretudo em relação à sua própria natureza.

Trata-se de um desenvolvimento dialético que conduz à autonegação da moral cristã, que consiste em levar às últimas consequências os valores que constituem a própria essência do Cristianismo, na medida em que esta se apoia numa "fé paradoxal e (em ligação com ela) numa exigência 
antinatural, isto é, voltada contra a natureza do homem" (GRAU, 1958, p. 11). Que essa dialética se desenvolve desde o próprio cerne da moral cristã pode ser constatado pela hesitação de Nietzsche em compor sua alegoria da morte de Deus. Antes de sua formulação definitiva, no aforismo 125 de A Gaia Ciência, Nietzsche havia experimentado a composição da cena como suicídio:

Deus está morto - quem, então, o matou? Também esse sentimento, de ter matado o mais santo, o mais poderoso, tem ainda que vir sobre os homens - agora é ainda demasiado cedo! ... Aqui calou-se Zaratustra novamente, e caiu em profunda meditação. Por fim, disse ele como que sonhando: ou matou-se ele próprio? Fomos nós apenas as suas mãos? (KSA 9, p. 591, 603).

A autorreflexão de Nietzsche consiste num acompanhamento detalhado, implacavelmente rigoroso, das consequências do acontecimento epocal que ele alegoricamente denominou 'a morte de Deus', e que consiste no esvaziamento de sentido e de cogência dos supremos valores da religião e da moral cristãs. No prefácio escrito para a segunda edição de Aurora, um daqueles seus prefácios autocrítico e autorreflexivos, datados de 1886, Nietzsche escreve:

Quem sabe se o pessimismo alemão não tem ainda seu último passo a dar? Quem sabe se ele precisa, ainda uma vez, de maneira terrível, colocar lado a lado o seu credo e seu absurdum? E se este livro, moral adentro, e até por sobre a confiança na moral é pessimista - não seria ele, precisamente por isso, um livro alemão? Pois de fato expõe uma contradição e não se amedronta diante dela: nele é retirada à moral a confiança - mas por que? Por moralidade! Ou como deveríamos chamar o que se passa nele, em nós? Pois por nosso gosto preferiríamos palavras mais modestas. Mas não há dúvida nenhuma, também em nós fala um 'tu deves', também nós obedecemos ainda a uma rigorosa lei acima de nós - esta é a última moral, que se faz ouvir a nós também, que nós também ainda sabemos viver; aqui, se é que em alguma parte, nós também somos ainda homens de consciência: isto é, não queremos retornar àquilo que para nós está sobrevivido e murcho, a algo 'desacreditado', quer se chame Deus, virtude, verdade, justiça, amor ao próximo; nós não permitimos nenhuma ponte de mentiras que leve a velhos ideais; desde o fundamento somos inimigos de toda espécie de crença e Cristianismo de agora; somos inimigos do meioa-meio, de todo romantismo e patriotismo; - somente como homens desta consciência sentimo-nos ainda aparentados com a retidão e a devoção alemãs de milênios, mesmo que como seus mais problemáticos e últimos descendentes, nós imoralistas, nós os sem-Deus de hoje, e até mesmo, em 
certo sentido, como seus herdeiros, como executores de sua mais íntima vontade. Em nós se consuma, suposto que queirais uma fórmula - a auto supressão da moral. (A Prefácio 4).

Do ponto de vista da interpretação de Nietzsche, o autoaniquilamento da religião e da moral cristãs, resultado lógico do idealismo alemão, revela sua essência mais íntima como consumação da dialética entre fé e razão. Credo quia absurdum est representa para Nietzsche a entrada em cena da lógica alemã na história do Cristianismo; e representa também o prenúncio da agonia do espírito do Cristianismo. Seu destino caminha largamente em direção de seu cumprimento filosófico por meio da interpretação luterana da sentença de Tertuliano.

Com efeito, para Lutero, não careceríamos de fé, se pudésssemos apreender pela razão os impenetráveis desígnios da Providência, especialmente como a Suprema Bondade pode permitir a existência do Mal no mundo. Kant, por sua vez, com seu programa crítico, levou esse ‘pessimismo alemão’ de Lutero até o paroxismo da radicalidade. De acordo com a interpretação de Nietzsche, a força de atração da sentença de Tertuliano manteve cativo também o espírito de Kant. Para preservar um espaço para o fé, e tornar inacessível o âmbito da moralidade ao ataque crítico da razão, foi obrigado a encerrá-lo numa modalidade sui generis de absurdum, de domínio incondicionado 'além da lógica', estabelecendo assim limites e fronteiras para o uso legítimo da razão teórica.

Na trilha destinamental aberta pela sedução da frase de Tertuliano, a que sucumbiu o genuíno espírito alemão, aproximadamente:

Um milênio mais tarde, nós alemães de hoje, alemães tardios sob todos os aspectos, farejamos - algo de verdade, de possibilidade de verdade, por detrás da célebre proposição fundamental real-dialética, com que Hegel em seu tempo ajudou o espírito alemão a triunfar sobre a Europa 'a contradição move o mundo, todas as coisas são contraditórias em si mesmas' - somos, justamente, até mesmo lógica adentro, pessimistas. (A Prefácio 3).

O aprofundamento desse mesmo pessimismo conduz ao ateísmo de Schopenhauer, o primeiro ateísta alemão de rigeur. Um ateísmo radical, anti-hegeliano por essência, incondicionado, colocado como pressuposto de sua filosofia, expressa também a retidão intransigente desse grande pessimista. Com essa retidão, segundo a interpretação de Nietzsche, o espírito alemão conduz a consciência europeia a uma vitória final, penosamente conquistada: 
Como o atao mais reico de conseqüências de uma disciplina de dois milênios para a verdade, que por fim se proíbe a mentira de acreditar em Deus[...] Vê-se o que propriamente triunfou sobre o Deus cristão, o conceito de veracidade tornado cada vez mais rigorosamente, o refinamento de confessores da consciência cristã, traduzido e sublimado em consciência científica, em asseio intelectual a qualquer preço[...] é por esse rigor, se é que por alguma coisa, que somos justamente bons europeus e herdeiros da mais longa e corajosa autosuperação da Europa. (GC 357).

Semelhante tragédia de autoesclarecimento se verifica também na figura da autossupressão da vontade de verdade, que penso ser possível aproximar da vertente lógico-cognitiva da Aufklärung. Desse modo, em Nietzsche, à denegação da moral por moralidade (ou seja, por dever de probidade intelectual), corresponde a catástrofe da vontade de verdade por exigência de veracidade.

$\mathrm{Na}$ busca da verdade, os filósofos teriam se conduzido sempre como se tivessem embotada ou entorpecida a potência da crítica do pensamento. Inclusive aqueles que, como Kant, tomaram a seu cargo o empreendimento de uma crítica da faculdade de conhecimento, ou da razão. Nunca foi colocada sob suspeita, como um problema filosófico digno de ser pensado, justamente a vontade incondicional de verdade, a busca da verdade a qualquer preço. Por não ter realizado sua autocrítica, essa vontade nunca foi efetivamente radical.

A exigência incondicional da verdade, que enuncia para os filósofos as perguntas que eles se formulam, é denominada por Nietzsche de veracidade (Wahrhaftigkeit). A radicalização da veracidade se produz quando a consciência filosófica aprende, com a própria vontade de verdade, a formular sua questão definitiva, ou seja, não mais aquela que se dirige à causa, mas aquela que se volta para o valor da veracidade, e isso de um duplo ponto de vista: questionandose pela origem desse valor (quem quer a verdade, o que em nós quer incondicionalmente a verdade), assim como o valor dessa origem:

Quem é propriamente que aqui me coloca questões? O que em mim 'quer' propriamente a verdade? O problema do valor da verdade colocou-se diante de nós - ou fomos nós que nos colocamos diante dele? Quem de nós é aqui Édipo? Quem é a esfinge? É um rendez-vous de perguntas e respostas. (ABM 1).

Posto que somos nós quem queremos a verdade a todo preço, o que revela de nós essa vontade incondicional de verdade? Por que não antes a incerteza, a ignorância, a inverdade, o erro? É porque queremos conhecer a 
verdade sobre a vontade de verdade (e, portanto, sobre nós mesmos, já que somos nós, ou algo em nós, que quer a verdade) que somos compelidos a formular a pergunta pelo valor, a pergunta crítico-genealógica por excelência, posto que é ela que libera a perspectiva da origem (para além do horizonte de visibilidade da pergunta metafísica tradicional). Ora, essa origem, na medida em que se revela na pergunta pelo valor, é desde sempre ligada a condições de existência, pois valores são pontos de vista de condições de existência, conservação e incremento de formações vitais no interior do vir-a-ser. Valor é um conceito indissociável, para Nietzsche, de modos e condições de existência, valor é sempre valor para alguém que avalia.

Sob essa ótica, desconstitui-se a supostamente legítima pretensão de validade incondicional da vontade de verdade, e seu valor se coloca então como um problema a ser pensado. Se a pretensamente incondicional veracidade se explica, no fundo, a partir de uma avaliação, de escolha valorativa, é porque a verdade como valor (e, por conseguinte, a vontade que a coloca como fim incondicional) deve ser pensada no registro (relativo e condicional) das condições de existência, fincando raízes, portanto, no profano solo histórico das relações de força, poder, domínio. "Até que ponto nosso intelecto é uma consequiência de condições de existência - nós não o teríamos, se dele não necessitássemos, e não o teríamos desse modo, se pudéssemos viver de outra maneira" (KSA 13, p. 185).

Percebe-se como os seguintes trechos da Dialética do Esclarecimento podem parecer ecoar a análise de Nietzsche:

O sistema, no sentido do Esclarecimento, é a forma do conhecimento que melhor dá conta dos fatos, que dá sustentação ao sujeito no domínio da natureza do modo mais eficaz possível. Seus princípios são aqueles da auto-conservação. Menoridade se demonstra como a incapacidade de se auto-conservar. O burguês, nas figuras sucessivas do escravocrata, do empresário, do administrador, é o sujeito lógico do Esclarecimento. (HORKHEIMER; ADORNO, 1987, p. 106).

Também para Horkheimer e Adorno revela-se a espúria cumplicidade entre a suposta assepsia da racionalidade lógica e a servil necessidade constringente de autoconservação:

O ser é percebido sob o aspecto da elaboração e da administração.Tudo se torna processo repetível, substituível, mero exemplo para os modelos conceituais do sistema, também o homem singular, para não falar dos animais. 
O conflito entre a ciência administrativa, reificadora, entre o espírito público e a experiência do indivíduo é prevenido pelas circunstâncias. Os sentidos são já previamente determinados pelo aparato conceitual, antes que ocorra a percepção, o burguês vê a priori o mundo como a matéria a partir da qual ele o constrói para si. (HORKHEIMER; ADORNO, 1987, p. 107).

O Esclarecimento não pode se furtar ao reconhecimento de que a razão constitui a dimensão da medialidade pura, com supressão de todos os fins particulares. Ela é instrumento de cálculo para o planejamento da vida, para exploração e dominação.

A concordância do universal com o particular também não está mais ocultamente contida num intelecto que percebe o particular a cada vez apenas como caso do universal, e o universal apenas como o lado do particular, pelo qual este se deixa apreender e manipular. A própria ciência não tem nenhuma consciência de si, ela é ferramenta. O Esclarecimento, porém, é a filosofia que identifica a verdade com o sistema científico. (HORKHEIMER; ADORNO, 1987, p. 107).

Os traços servis da penúria e da carência lançam sua sombra sobre os nobres traços da razão esclarecida. Autocrítica da razão produz a consciência de que: a autoconservação constitui o princípio da ciência:

A alma do quadro de categorias, também quando elas devem ser deduzidas idealisticamente, como em Kant. O próprio Eu, que opera a unidade sintética da apercepção, a instância que Kant denomina o ponto mais elevado do qual temos de pendurar a lógica toda, é, em verdade, o produto tanto quanto a condição da existência material. Os indivíduos, que têm de cuidar de si próprios, desenvolvem o eu como a instância de previsão e da visão de conjunto, ele se alarga e atrofia com as perspectivas de autonomia científica e propriedade produtiva através da cadeia de gerações. (HORKHEIMER; ADORNO, 1987, p. 110).

Retornando ao ponto de vista de Nietzsche, com esse reconhecimento a consciência filosófica esclarecida consolida, ao mesmo tempo, dois resultados fundamentais: em primeiro lugar, a vontade supostamente incondicional revelou sua pudenda origo, ou seja, revelou seu condicionamento e sua relatividade a condições de conservação e incremento, ou seja, a relações de poder, que são o contrário de exigências incondicionais. Sob esse aspecto, o território até então firme e seguro da vontade de verdade se desestabiliza como fundamento inconcusso, e se desfaz sob nossos pés. 
Em segundo lugar, a pergunta pela origem revela a verdadeira natureza caudatária das oposições lógico-cognitivas de valor. A exigência incondicional da verdade é, em verdade, a exigência da verdade como valor absoluto, como incondicionado. Ora, o domínio do incondicionado é a pátria originária da moral. De modo que a veracidade que anima a ratio filosófica acaba por se demonstrar duplamente comprometida: em seu inverídico condicionamento, e em sua natureza moral. É por isso que Nietzsche pode afirmar com tanta convicção, no prefácio de Aurora, que "os juízos lógicos não são os mais profundos e mais fundamentais a que pode descer a ousadia de nossa suspeita: a confiança na razão, com que se sustenta ou cai a validez desses juízos é, sendo confiança, um fenômeno moral..." (A Prefácio 4).

Assim, num estrato mais profundo do que as oposições lógicas de valor (verdadeiro, falso), encontram-se oposições de valor que são morais (bem, mal), de modo que a vontade de verdade é, então, sustentada pela moral. Com isso, tem-se também a resposta para a pergunta sobre a verdade a respeito de nós mesmos: quem somos nós, os que queremos incondicionalmente verdade, o que em nós quer incondicionalmente a verdade?

Resposta: a ânsia do incondicionado, o anelo do absoluto, ou seja, a necessidade de porto seguro, de sustentáculo, de redenção, de referências supremas de valor moral, ainda que como sucedâneos do Deus morto. Portanto, o que em nós quer a verdade é justamente a dor torturante do vazio deixado pelo absoluto perempto, é a carência de segurança do homo metaphysicus, e sempre o foi. A figura esclarecida e moderna da vontade de verdade é apenas o sucedâneo científico, laicizado e moralmente sacramentado, do anseio religioso pela pátria originária do Incondicionado, na qual Platão localizara a habitação originária da alma, ou do que nela há de aparentado com o divino.

Por essa razão, o sacrílego, o ímpio e assassino escrutínio críticogenealógico da vontade de verdade (essa autovivissecação que a moderna consciência científica não pode elidir, para ser fiel à sua própria origem) é também o último resíduo de sua devoção ancestral.

Mas já terão compreendido onde quero chegar, isto é, que a nossa fé na ciência repousa ainda numa crença metafísica - que também nós, que hoje buscamos o conhecimento, nós, ateus e anti-metafísicos, ainda tiramos nossa flama daquele fogo que uma fé milenar acendeu, aquela crença cristã, que era também de Platão, de que Deus é a verdade, de que a verdade é divina... Mas como, se precisamente isto se torna cada vez menos digno de crédito, se nada mais se revela divino, com a possível exceção do erro, da cegueira, da mentira - se o próprio Deus se revelou como a nossa mais longa mentira? (GC 344). 
O resultado da crítica, pois, não consiste no acesso a uma veracidade mais verdadeira, ou veraz, do que a da racionalidade tradicional, que transporia o velho ideal num nível ou patamar ainda superior. O resultado é a autossupressão da vontade de verdade, a catástrofe em que esta se abisma ao fazer a experiência de sua própria origem - e do valor (inverídico) dessa origem. O que não pode mais subsistir, como conclusão dessa dialética da vontade de verdade, é o resíduo, ainda que volátil, de uma oposição ainda subsistente entre uma veracidade aparente e uma verdadeira veracidade.

Ao final do experimento, a vontade de verdade é lançada na perplexidade da indiferenciação, numa zona cinzenta, para além dela mesma: "Por que nós a escolhemos, essa [louca] tarefa? Ou, perguntando de outro modo: 'Por que conhecimento, afinal?' Todos nos perguntarão isso. E nós, premidos desse modo, nós, que já nos fizemos mil vezes a mesma pergunta, jamais encontraremos resposta melhor que..." (ABM 230). Portanto, uma resposta que necessariamente falta, se posta no território da verdade. Em termos da oposição entre 'falso' e 'verdadeiro', só é permitido doravante expressar-se entre aspas, por ironia.

Portanto, o entendimento inteiramente emancipado pelo desencadeamento de todas as suas forças, ao extrair as últimas consequências da lógica de seus próprios valores, chega à sua derradeira verdade, que consiste propriamente na agonia da vontade de verdade, na indistinção entre verdade e falsidade, esses supremos produtos da poiesis humana.

Depois que a veracidade cristã tirou uma conclusão depois da outra, ela tira, no fim, sua mais forte conclusão, a conclusão contra si mesma; isso, porém, acontece quando ela coloca a questão: 'e que significa toda vontade de verdade?'[...] E aqui toco outra vez em meu problema, em nosso problema, meus amigos desconhecidos: Que sentido teria nosso ser inteiro, se não o de que, em nós, aquela vontade de verdade teria tomado consciência de si mesma como problema? Nesse tomar consciência de si da vontade de verdade vai, de agora em diante - disso não há nenhuma dúvida - a moral ao fundo. (GM III 27).

Com a perempção da moral, vítima da radicalização da veracidade, do tomar consciência de si, como problema, da vontade de verdade, conduz a ciência filosófica ao mais paradoxal dos resultados: um ‘verdadeiro' filósofo só pode sê-lo por ironia (suprema vingança do demônio de Sócrates?), pois é lícito colocar em dúvida que um filósofo possa doravante ter, em absoluto 'convicções definitivas e autênticas’, é sempre lícito e necessário suspeitar se justamente nele não há: 
Não tenha de haver, uma caverna ainda mais profunda por detrás de cada caverna - um mundo mais amplo, mais rico, mais estranho além da superfície, um abismo atrás de cada chão, cada razão, por baixo de toda 'fundamentação'.Toda filosofia também esconde uma filosofia, toda opinião é também um esconderijo, toda palavra também uma máscara. (ABM 289).

Creio poder avançar ainda outra complementaridade surpreendente: é muito conhecida a reversão dialética entre mito e esclarecimento problematizada por Horkheimer e Adorno.

O princípio da necessidade fatalística à qual sucumbem os heróis do mito, e que se extrai da sentença oracular como conseqüência lógica, depurada como adstringência da lógica formal, domina não apenas em todo sistema racionalista da filosofia ocidental, mas impera até sobre a conseqüência dos sistemas, que principia com a hierarquia dos deuses e, em permanente crepúsculo dos ídolos, transmite, como o idêntico conteúdo, a ira contra a insuficiente retidão. ${ }^{*}\{$ Alusão à censura à falta de correção, retidão e probidade suscitada pelos positivistas face aos filósofos metafísicos, e em geral por todo pensamento 'esclarecedor' face aos sistemas filosóficos precedentes. (A. d. i. Ü.) \}. Como já os mitos realizam o Esclarecimento, do mesmo modo o Esclarecimento enreda-se mais profundamente a cada passo na Mitologia. Todo conteúdo ele o recebe dos mitos, para destruí-los, e como julgador ela sucumbe à maldição mítica. (HORKHEIMER; ADORNO, 1987, p. 33).

Um enredamento semelhante pode ser atestado na metáfora nietzschiana, de acordo com a qual a moderna cultura científica, tendo chegado ao limite de suas possibilidades lógicas, 'acaba por morder a própria cauda', voltando-se contra si mesma, num processo de autodissolução.

Lessing, o mais honesto dos homens teóricos, atreveu-se a declarar que a ele importava mais a busca da verdade do que esta mesma: com isso ficou a descoberto o segredo fundamental da verdade, para perplexidade, mais ainda, para a irritação dos cientistas. Certamente, junto a esse conhecimento isolado encontra-se, como um excesso de honestidade, senão de soberba, uma profunda representação delirante, que pela primeira vez veio ao mundo na pessoa de Sócrates - aquela crença inabalável de que, seguindo o fio condutor da causalidade, o pensar alcança até os abismos mais profundos do ser, e que o pensar é capaz não somente de conhecer o ser, mas até de corrigi-lo. Esta 
sublime delírio metafísico foi acrescentado como instinto à ciência, e a conduz, sempre e sempre de novo, até aqueles limites nos quais ele tem de se converter em arte: que é o que propriamente se tem em vista nesse mecanismo. (NT 15).

O desdobrar-se dessa potência consiste num incessante arrancar véu após véu, que impele a racionalidade científica sempre avante, compulsivamente em busca da verdade, pois é a procura que constitui o verdadeiro interesse, a busca infinita, mais que a verdade episodicamente desvelada. Também em Nietzsche aparece uma imbricação reversível entre lucidez e delírio, emancipação e compulsão. Para ele, a força que, do interior, anima o progresso da razão esclarecida é haurida numa Wahnvorstellung, ou seja, numa obscura potência delirante, que afinal acaba por ser compelida a revelar sua verdadeira natureza:

Mas agora a ciência, aguilhoada por sua vigorosa ilusão, corre pressurosa e irrefreável até aqueles limites, nos quais fracassa seu otimismo, oculto na essência da lógica. Pois a periferia do círculo tem muitos e infinitos pontos, e enquanto ainda não é possível prever de modo algum como poderia alguma vez ser completamente medido o círculo, o homem nobre e talentoso atinge de maneira inevitável, e antes de chegar à metade de sua existência, tais pontos fronteiriços da periferia, onde ele se detém naquilo que é impossível de esclarecer. Quando ele vê aqui, para seu espanto, como a lógica, chegando a esses limites, enrosca-se sobre si mesma e finalmente morde a própria cauda. (NT 15).

Trata-se de um percurso verdadeiramente trágico, aos olhos de Nietzsche, pois nele a racionalidade científica se encaminha, motu proprio, em direção à perempção, pois uma cultura assentada no princípio da cientificidade tem de sucumbir tão logo comece a se tornar ilógica, isto é, a recuar diante de suas próprias inevitáveis conclusões, evitando levar às derradeiras consequências a lógica de seus próprios valores.

Enquanto o infortúnio que dormita no seio da cultura teórica começa a angustiar pouco a pouco o homem moderno, e este, inquieto, recorre a certos meios para conjurar o perigo, retirando-os do tesouro de sua experiência, sem acreditar realmente, ele próprio, em tais meios; quer dizer, enquanto o homem moderno começa a pressentir suas próprias conseqüências: certas naturezas grandes, de inclinações universais, souberam utilizar com incrível sensatez o arsenal da própria ciência para mostrar os limites e o caráter condicionado do conhecer em geral, e para 
negar com isso decididamente a pretensão da ciência de possuir uma validez universal e metas universais: e essa demonstração foi reconhecida pela primeira vez como tal aquela representação delirante que, pela mão da causalidade, se arroga a pretensão de poder de perscrutar a essência mais íntima das coisas. (NT 18).

Também podemos perceber em Nietzsche que o 'tornar-se ilógico' da modernidade científica tem seu correspondente político na denegação da dominação e da exploração. O otimismo encastelado na essência da lógica e da dialética prometia a libertação do medo ancestral e o domínio integral das forças da natureza. O que acontece quando os frutos desse otimismo amadurecem, no plano da sociedade, e esta passa a exigir o cumprimento das promessas de felicidade terrestre universal? Para Nietzsche, também a cultura fundada no princípio da racionalidade científica tem como condição de existência o reino do trabalho, da necessidade, da não-liberdade. No entanto, em seu otimismo, essa cultura é levada à necessidade de denegação dessa dependência.

Por isso, uma vez consumido e desgastado o efeito das:

Belas palavras sedutoras e tranqüilizadoras a respeito da 'dignidade do ser humano' e da 'dignidade do trabalho', [ela] se encaminha pouco a pouco na direção de uma horripilante aniquilação. Nada há de mais terrível do que um estamento bárbaro de escravos que tenha aprendido a considerar sua existência como uma injustiça, e que se disponha a tirar vingança não somente por si mesmo, como para todas as gerações. Frente a tais ameaçadoras tempestades, quem se atreverá a apelar com ânimo seguro a nossas pálidas e fatigadas religiões, que degeneraram em seus fundamentos até converter-se em religiões de doutos: de tal modo que o mito, pressuposto necessário de toda religião, já está por toda parte tolhido, e até mesmo nesse domínio conseguiu impor-se aquele espírito otimista, do qual acabamos de dizer que é o germe do aniquilamento de nossa sociedade. (NT 18).

Se, para Nietzsche, a dominação não pode mais ocultar-se em sua verdade, uma vez desgastado o efeito sedutor das representações tranquilizadoras, o mesmo se verifica em Horkheimer e Adorno (1987, p. 116):

O instrumento, com o qual a burguesia chegou ao poder, desencadeamento das forças, liberdade universal, autodeterminação, em resumo, o Esclarecimento, voltou-se contra a burguesia, tão logo ela, como sistema de dominação, foi compelida à repressão. O Esclarecimento, em conformidade com seu princípio, não se detém nem mesmo perante o 
mínimo de crença, sem o qual o mundo burguês não pode existir. Ela não proporciona para a dominação o serviço confiável, que a ela foram prestados sempre pelas velhas ideologias. Sua tendência anti-autoritária que, embora apenas subterraneamente, se comunica com aquela utopia no conceito da razão, a torna finalmente, para a burguesia estabelecida, tão hostil quanto a aristocracia, com a qual esta também então se reuniu logo cedo. O princípio anti-autoritário tem, finalmente, de se converter em seu próprio contrário, em instância contra a própria razão: a destruição, levada a efeito por esse princípio, de tudo o que em si mesmo é obrigatório, permite à dominação decretar e manipular soberanamente as obrigações que, a cada vez, são para ela adequadas. Depois da virtude burguesa e da filantropia, para as quais ela não tinha mais nenhuma boa razão, a filosofia propalou então também a autoridade e a hierarquia como virtudes, quando estas, há tempo, em virtude do Esclarecimento, tinham se tornado mentiras. Porém, mesmo contra tal perversão de si mesmo, o Esclarecimento não tinha nenhum argumento; pois, perante a ratio, a verdade mais pura não goza de qualquer privilégio sobre o disfarce, a racionalização, se ela não evidenciou nenhum privilégio prático a seu favor. Com a formalização da razão, a própria teoria se torna, na medida em que quer ser mais do que um signo para modos neutros de procedimento, um conceito incompreensível, e o pensamento vale como significativo somente depois da renúncia ao sentido. Atrelada ao modo de produção dominante, o Esclarecimento, que anseia pelo solapamento da ordem tornada repressora, dissolve-se a si mesmo.

Eis, portanto, de onde se nutre o vigor da crítica de Nietzsche: nela se consuma a autodissolução do Esclarecimento, entendido como filosofia da ordem opressora e repressiva. A brutalidade teórica da moral dos senhores e dos escravos é a contra-face da denúncia antecipatória da barbárie vigente na dominação real, recusa intransigente da edulcoração hipócrita da violência. No fundo, a realização efetiva da genealogia pode ser vista como o avesso de seu cinismo patente - e justamente por isso como exposição do cancro que consome por dentro o processo civilizatório ocidental.

Ao elevar o culto da força a doutrina histórico-universal, o fascismo alemão conduziu-o, ao mesmo tempo, ao próprio absurdo. Como objeção contra a civilização, a moral dos senhores denuncia, inversamente, os opressores: o ódio contra os instintos atrofiados denuncia objetivamente a verdadeira natureza dos amestradores, que vem à luz em suas vítimas. Como grande potência, porém, e como religião do estado, a moral dos senhores se coloca inteiramente à mercê dos poderes civilizatórios that be, da compacta maioria, ao 
ressentimento e a tudo contra o que ela uma vez esteve. Nietzsche é refutado pela própria efetivação, e ao mesmo temo a verdade nele é liberada, que apesar de todo dizer-sim à vida, era hostil ao espírito da efetividade. (HORKHEIMER; ADORNO, 1987, p. 124).

É inegavelmente oportuno, nesse contexto, evocar a metáfora dos construtores de casas, em Assim Falou Zaratustra: quando o personagem título se dispôs a verificar se entrementes o homem se tornara maior ou menor, ele se impressiona precisamente diante da aparência de suas casas:

E, uma vez, vendo uma série de casas novas, admirou-se e disse: Que significam essas casas? Em verdade, não foi uma grande alma que as colocou aí à própria semelhança ... E esses aposentos e essas câmaras! Há homens que consigam entrar e sair daí? Parecem-me feitos para bonecas de seda ou para gulosos, que também deixam que neles se deguste algo. (ZA Da Virtude Amesquinhadora).

É no espírito dessa brutal denúncia da pequenez dos amestradores, das potências que gerenciam a regressão do humano como barbárie civilizada, como rebaixamento de valor e domesticação do homem, que a genealogia nietzschiana reata com a utopia contida no conceito kantiano de razão: aquele ideal de uma livre vida em comum, na qual os homens se organizariam como sujeito universal; ou seja, numa universalidade verdadeira, em que a particularidade das diferenças acidentais entre as pessoas seria suprassumida na identidade, até então reprimida, de seus interesses fundamentais.

Assim, a civilização conduz de volta à terrível natureza, como a seu derradeiro resultado. $\mathrm{O}$ amor mortal, sobre o qual, em Sade, incide toda a luz da apresentação, e a soberba pudendamente sem-vergonha de Nietzsche, que desejaria a todo preço poupar o sofredor do envergonhamento: a imaginação da crueldade como a da grandeza procede no jogo e na fantasia tão duramente com os homens como então o fascismo alemão o faz na realidade. Todavia, enquanto o colosso do efetivo, sem consciência, o capitalismo sem sujeito, realiza cegamente a aniquilação, o delírio do sujeito rebelde deixa-se dever a ela sua realização, e assim irradia com incisiva frieza sobre os homens maltratados como coisas o amor invertido que no mundo das coisas toma o lugar do amor imediato. A doença se torna sintoma do convalescer. O delírio reconhece na transfiguração da vítima sua humilhação. Ele se iguala ao colosso da dominação, que ele não pode superar corporalmente. Como horror, a imaginação procura confrontar o horror. (HORKHEIMER; ADORNO, 1987, p. 131). 
Em conclusão, o que permanece em aberto parece ser uma diferença irreconciliável, no fundo de tantas analogias e aproximações. Horkheimer e Adorno parecem denunciar o enredamento do Esclarecimento com o mito, da racionalidade com a dominação e a barbárie totalitária enquanto um processo determinado por uma imbricação histórica mais fundamental - a saber o vínculo entre razão técnico-científica e a organização social das relações de produção, fundada na apropriação privada dos meios e forças produtivas.

O saber que é poder não conhece nenhuma barreira, nem na escravidão da criatura, nem na condescendência para com os senhores do mundo. Assim como tudo se dispõe em relação às finalidades da economia burguesa na fábrica e no campo de batalha, assim também tudo se dispõe para os empresários, sem consideração de sua proveniência. Os reis não dispõem mais imediatamente sobre a técnica do que os comerciantes: ela é tão democrática quanto o sistema econômico com o qual se desenvolve. A técnica é a essência desse saber. Ele não visa conceitos e figuras, a felicidade do discernimento, mas visa método, exploração do trabalho dos outros, capital. (HORKHEIMER; ADORNO, 1987, p. 26).

De acordo com esse diagnóstico, bem se poderia concluir que o elemento problemático no conceito iluminista de razão é que sua suposta unidade e universalidade estaria em contradição real com as condições sócio-históricas de sua realização. Nesse sentido, a oposição entre o eu transcendental e o eu empírico seria expressão simbólica da contradição econômica que atravessa a ordem social do capitalismo monopolista.

Os conceitos de Kant são de duplo sentido. Como eu transcendental e supra individual, a razão contém a idéia de uma livre vida em comum dos homens, ao se organizarem em um sujeito universal e suprimir a oposição entre a razão pura e empírica na consciente solidariedade do todo. Isso exibe a idéia da verdadeira universalidade, a utopia. Ao mesmo tempo, contudo, a razão forma a instância do pensamento calculador, que dispõe o mundo para os fins da auto-conservação, e não conhece outras funções senão a preparação do objeto a partir do simples material sensível em material da sujeição. (HORKHEIMER; ADORNO, 1987, p. 106).

Considero que, em Nietzsche, a dialética catastrófica da racionalidade esclarecida não provém de seu enraizamento num determinado modo de organização do trabalho social e no regime econômico-jurídico da apropriação de seus produtos. O filósofo da vontade de poder tem uma concepção 'metafísica' 
da exploração e das relações de domínio - até mesmo no mais espiritualizado de seus campos de incidência, aquele da filosofia. Por isso mesmo, uma perspectiva redentora só se delineia no caminho e na direção da espiritualização e da sublimação crescentes das potências telúricas do bicho homem. Por isso mesmo, a genealogia de Nietzsche nos ensina que não é na estabilidade de uma natureza reconquistada, perene e pacificada, mas na impermanência do instável e sempre efêmero, do que se debate e declina, no que se encontra em trânsito e sempre estertora, é que o pensamento pode liberar algum conteúdo de verdade.

\section{Referências}

GRAU, G-G. Chirstlicher Glaube und Intellektuelle Redlichkeit. Frakfurt: Schulte-Bulmke, 1958.

HORKHEIMER, M.; ADORNO, Th. Dialektik der Aufklärung. In: HORKHEIMER, M. Gesammelte Schriften. Band 5. Frankfurt: Fischer Taschenbuch Verlag, 1987. p. 106.

KANT, I. Die Religion innerhalb der Grenzen der blossen Vernunft. Nota Geral, B 296. In: cap. 4. v. VI. Akademie Textausgabe. Berlin: Walter de Gruyter, 1968.

NIETZSCHE, F. Aurora. In: Obras incompletas. Tradução Rubens R. Torres Filho. São Paulo: Abril Cultural, 1974. p. 165. (Coleção Os Pensadores).

A gaia ciência. Tradução Paulo César de Souza. São Paulo: Companhia das Letras, 2001.

Para além de bem e mal. Tradução de Paulo César de Souza. São Paulo: Companhia das Letras, 2005.

Sämtliche Werke: Kritische Studienausgabe (KSA). Berlin: G. Colli und M. Montinari; New York: DTV, 1980.

Recebido: 20/03/2008

Received: 03/20/2008

Aprovado: 18/05/2008

Approved: 05/18/2008 